\title{
Latvia: A Historical Analysis of Transformation and Diversification of the Higher Education System
}

\author{
Ali Ait Si Mhamed, Zane Vārpina, Indra Dedze, \\ and Rita Kaša
}

\section{The Soviet Higher Education Landscape in Latvia}

Several of the contemporary higher education institutions (HEIs) in Latvia emerged at the start of the twentieth century and even before. Higher education in Latvia, one of the Baltic States with a population of approximately two million, is more than 150 years old and has developed through several transformations in different political and socioeconomic contexts.

The first HEI in Latvia was Riga Polytechnicum, later renamed Riga Polytechnic Institute, which was established in 1862 under the Russian

A. A. S. Mhamed $(\bowtie) \bullet$ R. Kaša

Nazarbayev University, Astana, Kazakhstan

Z. Vărpiņa

Stockholm School of Economics in Riga, Riga, Latvia

I. Dedze

Ventspils University College, Ventspils, Latvia

(C) The Author(s) 2018

259

J. Huisman et al. (eds.), 25 Years of Transformations of Higher

Education Systems in Post-Soviet Countries, Palgrave Studies in Global

Higher Education, https://doi.org/10.1007/978-3-319-52980-6_10 
Empire, first with German and then Russian as the language of instruction (RTU 2002, 2013). With the proclamation of the independent Republic of Latvia in 1918, the transformation of the higher education (HE) sector in Latvia continued. The first national HEI with Latvian as the language of instruction was established in 1919 on the foundations of Riga Polytechnic Institute (RTU 2013; LU 1999, 35). In 1923, this HEI was given the title University of Latvia. The development of the University of Latvia was a national priority, to which the government allocated $15 \%$ of the total national budget (LU 1999) between 1919 and 1940.

Several other HEIs were established during the first independence period. The Conservatoire of Latvia opened in 1919 and the Academy of Arts was established in 1921. These two institutions, like the University of Latvia, were located in the capital city of Riga. In 1939, the Department of Agriculture and Forestry separated from the University of Latvia (LU 2014) and became the Academy of Agriculture in Jelgava. The start of higher education in sports and teacher education in Latvia also dates back to the 1920s, when the government established the Latvian Institute of Physical Education and state teacher training institutes were opened in Daugavpils and Rezekne (LPE1 1981).

Political, social and economic shifts associated with the establishment of Soviet rule in Latvia prior to and after World War II shaped transformations in the higher education sector as well. In 1940, directly after the Soviet occupation, the University of Latvia was changed in name and structure: it became the State University of Latvia. Those occupying management and governance positions were replaced. The schools of theology were closed, other schools were renamed and departments were established for MarxismLeninism and other political and military disciplines (LU 2009). The twostream language model of instruction in Latvian and Russian was also introduced (LU 1999). In the Stalinist era of the Soviet period, higher education was characterised by ideological purges and the repression of faculty and students. It also marked the movement to separate science from higher education according to the Soviet model (LU 2009).

Ensuing transformations of the higher education sector involved continuing the diversification of the institutional landscape. It included relocating several HEIs from the supervision of the Ministry of Education to the supervision of the ministries of various sectors. Several new HEIs were established, some on the foundations of the existing structures established prior to 1940. Among those formed based on existing organisational structures were Rezekne State Pedagogical Institute established in 1941, 
the State Institute of Physical Culture established in 1946, Daugavpils Pedagogical Institute in 1952 and Liepaja Pedagogical Institute established in 1954. These HEIs were placed under the oversight of the Ministry of Education. In 1950, Riga Medical Institute was separated from the State University of Latvia and established as an independent HEI under the supervision of the Ministry of Healthcare (LPE1 1981, 485-487). Riga Polytechnic Institute, which initially formed the basis for the University of Latvia, was re-established as an independent HEI in 1958 (RTU 2002). A new institution was established in 1960, the Institute of Civil Aviation Engineering, the purpose of which was to prepare civil aviation professionals for the entire Soviet Union (LPE5 1984, 581). When Latvia proclaimed its independence from the USSR in 1990, the higher education system consisted of ten state HEIs; five HEIs were placed under the Ministry of Education and others were operating under the auspices of the ministries of healthcare, culture and agriculture (Table 10.1).

Higher education in Soviet Latvia was under full state control, organised to serve the needs of the centrally planned economy and the official Marxist-Leninist ideology. Institutional collaboration was limited to the HEIs of the Soviet bloc countries. The main focus of the higher education system was on the natural sciences and Soviet ideology, while social sciences and languages, except for Russian, were marginalised (Eglite 2009; Heyneman 2000). Higher education in Latvia was expected to add to the building of the Soviet state, reshaping the social structure along socioeconomic and ethnic lines (Karklins 1984; Walder 1990).

The number of study places to be filled per HEI and study programme was determined by the state. Students could apply to either a Russian or Latvian language variant of a study programme (LU 1999). The most popular study programmes at HEIs did not have difficulties selecting the best applicants, but there were different approaches to filling vacant study slots in the least popular study programmes. During Soviet times, the State University of Latvia offered admission to the least popular study programmes to students who failed to enter their preferred study programme. It also organised additional admissions to unpopular programmes for applicants who had failed to enter other HEIs (LU 1999, 231-234). There was some student mobility taking place across the Soviet Republics; every year there were students from other parts of the USSR admitted to HEIs in Latvia, while a few students from Latvia were also admitted to other Soviet Republics with little to no HE entry competition (LPE5 1984, 581). 
Table 10.1 Types of HEIs in Latvia by 1989 characteristics

\begin{tabular}{|c|c|c|c|}
\hline Type of HEI & Number of HEIs & $\begin{array}{l}\text { Ministerial } \\
\text { oversight }\end{array}$ & Type of HEI \\
\hline $\begin{array}{l}\text { Flagship } \\
\text { Public, located in Riga, } \\
\text { multidisciplinary, } \\
\text { undergraduate through } \\
\text { advanced graduate study } \\
\text { programmes }\end{array}$ & $\begin{array}{l}\text { 1 HEI } \\
\text { State University } \\
\text { of Latvia }\end{array}$ & $\begin{array}{l}\text { Ministry of } \\
\text { Higher and } \\
\text { Specialized } \\
\text { Secondary } \\
\text { Education } \\
\text { (MHSSE) }\end{array}$ & $\begin{array}{l}\text { Multidisciplinary } \\
\text { university }\end{array}$ \\
\hline $\begin{array}{l}\text { Public specialised HEIs } \\
\text { Public, specialised or } \\
\text { narrow specialisation, } \\
\text { teaching, undergraduate, } \\
\text { graduate and in some } \\
\text { cases advanced graduate } \\
\text { study programmes }\end{array}$ & $\begin{array}{l}9 \text { HEIs } \\
\text { Liepaja State } \\
\text { Institute of } \\
\text { Pedagogy } \\
\text { Daugavpils } \\
\text { Pedagogical } \\
\text { Institute } \\
\text { Riga Polytechnic } \\
\text { Institute } \\
\text { Latvia Academy } \\
\text { of Agriculture } \\
\text { Riga Medical } \\
\text { Institute } \\
\text { Conservatoire } \\
\text { of Latvia } \\
\text { Art Academy of } \\
\text { Latvia } \\
\text { State Institute of } \\
\text { Physical Culture } \\
\text { Institute of Civil } \\
\text { Aviation } \\
\text { Engineering }\end{array}$ & $\begin{array}{l}\text { MHSSE } \\
\text { Ministry of } \\
\text { Agriculture } \\
\text { Ministry of } \\
\text { Healthcare } \\
\text { Ministry of } \\
\text { Culture } \\
\text { Ministry of } \\
\text { Culture } \\
\text { MHSSE } \\
\text { Ministry of } \\
\text { Civil Aviation }\end{array}$ & $\begin{array}{l}\text { Specialised in } \\
\text { teacher training } \\
\text { Specialised in } \\
\text { teacher training } \\
\text { Specialised in } \\
\text { technical education } \\
\text { Specialised in } \\
\text { agriculture } \\
\text { Specialised in } \\
\text { medical education } \\
\text { Specialised in arts } \\
\text { Specialised in arts } \\
\text { Specialised in sports } \\
\text { education } \\
\text { Specialised in } \\
\text { aviation and } \\
\text { transport }\end{array}$ \\
\hline
\end{tabular}

Source: Authors based on MoES data, bylaws and HEI websites

Although officially higher education in the USSR was free as it was entirely funded by the government, research documents the application of tuition fees and limited student financial assistance for various periods of time (DeWitt 1955; Dobson 1977). Tuition fees at the State University of Latvia were waived in 1957 and stipends were introduced (LU 1999, 259-260). Outstanding students had higher monthly stipends than average students (LVU 1982, 6). In 1989, tuition fees were reintroduced due to the admission of more students successfully passing the entrance examination than planned (LU 1999, 261). 


\section{Transformation of the Higher Education Sector SINCE 1990}

The transition period from the centrally planned Soviet system to a democratic liberal market economy in Latvia involved challenging economic and social burdens. There was a dramatic collapse of production and real income, accompanied by a surge in poverty and social inequality. The restructuring of the economy involved massive declines in agriculture and industry, resulting in unemployment and a decline in individual wellbeing. The transition pushed $22 \%$ of the population in Latvia under the poverty line. The recession did not level off until 1994, while poverty and inequality remained a persistent attribute of the new system (Norgaard et al. 1999). These challenging socioeconomic conditions formed the context for the transformations of the higher education sector in Latvia after 1990. At the same time, the national political priority of integration into European structures, which eventually led to Latvia becoming a full member of the European Union (EU) in 2004, provided the direction for higher education reforms. Accession to the EU and acquired global openness strengthened the Europeanisation and internationalisation of higher education in Latvia (Kaša and Ait Si Mhamed 2013, 34).

\section{Private Higher Education Institutions}

The most important accomplishments of the higher education reform during the transition period from the centrally controlled Soviet system to a democratically governed system were the expansion of the HE sector in terms of the number of institutions and students, the creation of private HEIs, the introduction of HE quality assessment, the development of new study programmes and the modernisation of existing study programmes, and the intensification of international cooperation between HEIs in Latvia and abroad (Rivža 2004, 71-72).

After independence, higher education reforms in Latvia were in line with the Bologna process that started in 1999 and aimed at creating a European Higher Education Area (EHEA) with enhanced academic mobility (Štefenhagena 2012). As part of this process, Estonia, Latvia and Lithuania created a common higher education area in 2000 by agreeing to recognise the higher education qualifications of the others. In the following years, the integration of Latvia's higher education system into the EHEA progressed. In 2007, the European Credit Transfer System (ECTS) was introduced, 
which allows for higher education comparison and recognition across the EU. Since 2012, Latvia has been a full-fledged member of the EHEA. Figure 10.1 presents the milestones of the post-independence period.

In addition to European orientation, a liberal market has dominated the underlying steering philosophy of the post-independence higher education reforms in Latvia. This has allowed for the emergence of one of the largest private HE sectors in the region (Pachuashvili 2009). It also provided public HEIs in Latvia with rather high levels of institutional autonomy as compared to other countries in Europe (EUA 2012). As a result, in 2014 there were 60 HEIs in Latvia enrolling 184,132 students (MoES 2015). While private colleges were newly created, most public colleges were established on the foundations of vocational schools that existed prior to 1990. In 2004, these vocational schools were essentially renamed and reorganised into public colleges providing short-cycle higher education in order to achieve integration with the EHEA. Figure 10.2 indicates developments in the number of HEIs in the country.

\section{Student Enrolment}

Since 1991, all HEIs in Latvia have autonomously decided the total number of students admitted annually. Immediately after independence, total

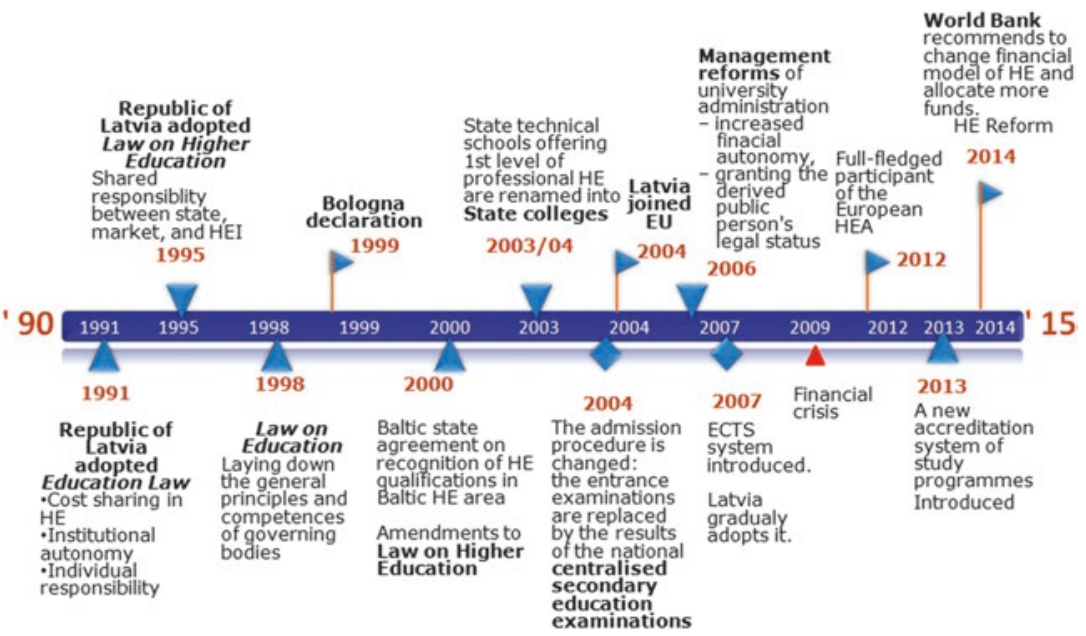

Fig. 10.1 Milestones in the development of the higher education system in Latvia, 1990-2014 (Source: Authors) 


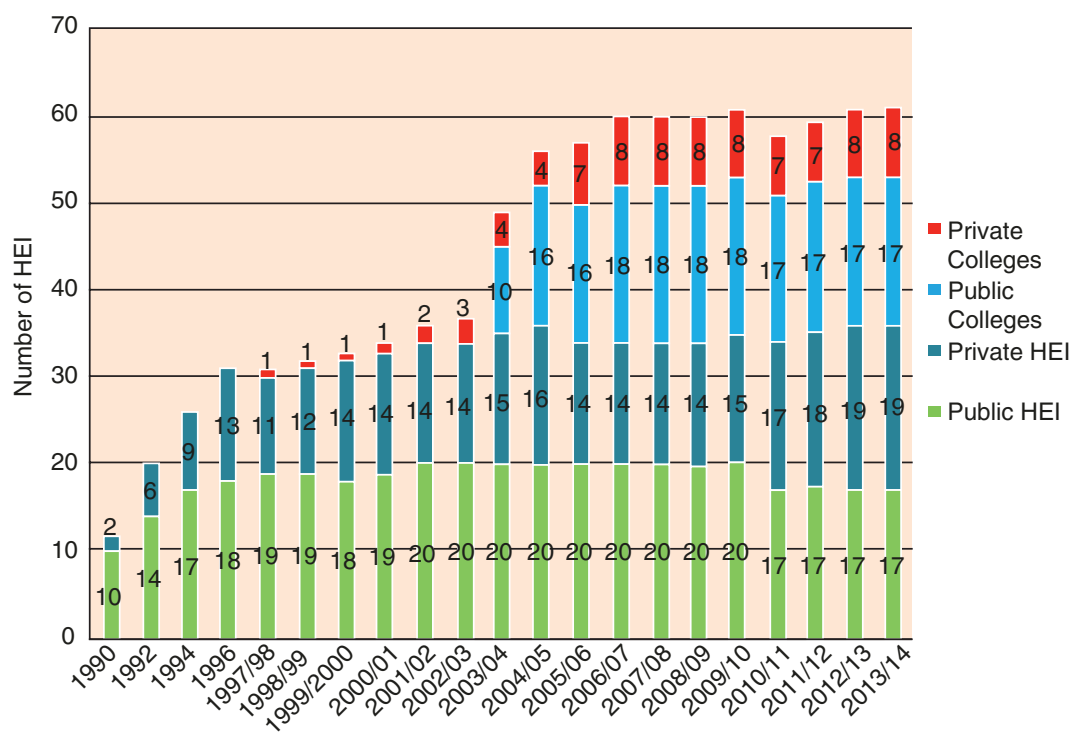

Fig. 10.2 The dynamics of HEIs in Latvia, 1990-2014 (Source: Authors based on data from MoES, 1991 to 2014)

student enrolment decreased from 42,000 in 1992 to 38,986 in 1993 because there were no more students coming in from the other former Soviet Republics (Latvijas Enciklopedija 2002). However, in the mid1990 s, the increase in the number of students resumed to reach 46,680 in 1994. Between 2005 and 2014, the total number of students in Latvia declined by $34 \%$ (MoES 2015) (see also Fig. 10.3).

Participation in higher education increased due to tuition-paying students. All students at private HEIs, with negligible exceptions, paid tuition. Public HEIs reminiscent of the Soviet era applied a dual-track tuition approach based on the idea of public procurement in higher education (Kaša and Loža 2001). That is, the government continued to provide funding to educate a certain number of students free of charge who studied alongside students paying tuition. Admission to these publicly funded study slots remained merit-based, taking into account only the applicant's grades (Kaša 2007). In 2004, admission to HEI undergraduate studies changed from independently organised entrance examinations to the standardised national secondary school leaving exams (Cabinet Regulations 846 2006; Saeima 1995a). In 2005, the number of fee-paying students as 


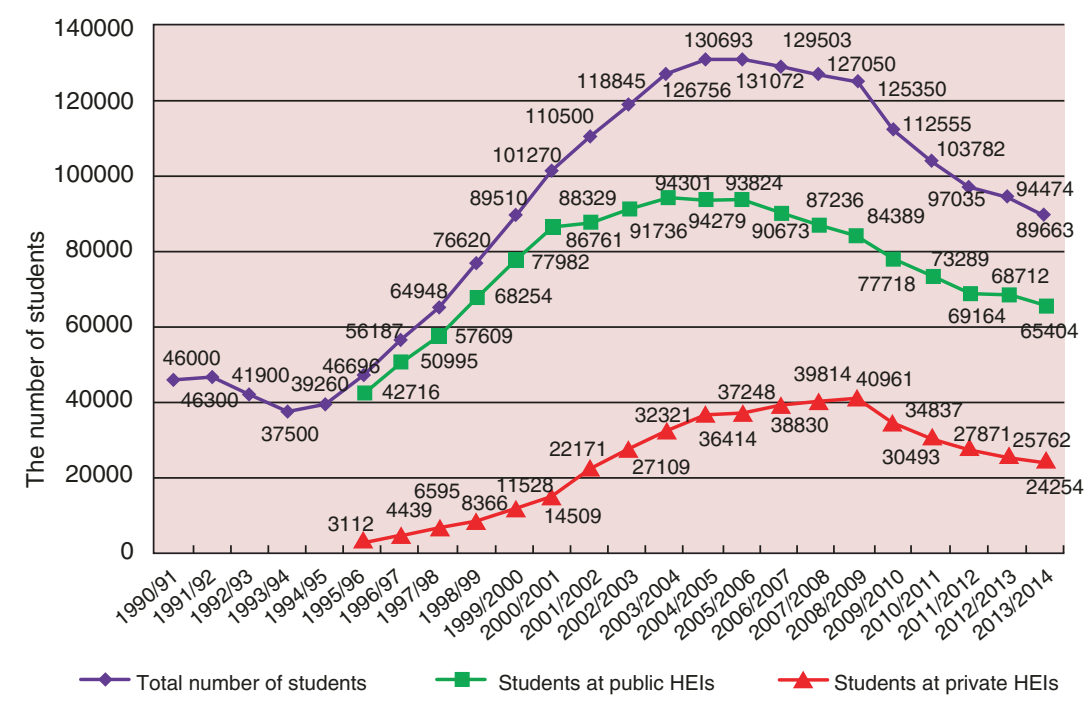

Fig. 10.3 The dynamics of HE student enrolment in Latvia, 1990-2014 (Source: Authors based on data from MoES, 1991 to 2014)

a proportion of the total number of students in the country reached $70 \%$, but this share started to decrease later, reflecting a demographic decline in traditional-age cohort students. In 2014, the proportion of tuition-paying students was $40 \%$ of all students in Latvia (MoES 2015).

\section{Legislation Regarding the Higher Education System}

According to the Law on Higher Education Establishments (Saeima, 1995a), Latvia has a binary higher education system, which pertains mostly to the level of study programmes and is not strictly institutionalised. This means that both university and non-university institutions in Latvia can run academic and professional study programmes, and most HEIs choose to do so. The only exceptions to this rule are colleges (firstlevel professional higher education institutions) which offer short-cycle tertiary education (ISCED 5 ) in the form of professional study programmes only (Eurydice 2014). Legislation in Latvia supports the mobility of higher education graduates from professional to academic higher education programmes and vice versa. 
The law of higher education institutions established the division of university and non-university institutions in 1995, prescribing conditions for the use of specific terms in HEI titles. The types of HEIs according to the law in Latvia are universities, academies, institutions of higher education and colleges (Saeima 1995a). The legislation allows for institutions to change their status and evolve over time from one type of institution to another. The process of a non-university institution becoming a university institution is illustrated by the example of Liepaja University, which was initially a narrowly specialised HEI that eventually transformed into a university (see Text Box 10.1).

\section{Text Box 10.1. The Case of Liepaja University}

Liepaja University is the youngest university in Latvia. It was established in 1954 as Liepaja Institute of Pedagogy and has since changed its name seven times, eventually acquiring university status in 2008 (Saeima 2008):

1. Liepaja Institute of Pedagogy (01.08.1954-19.06.1961)

2. Liepaja State Institute of Pedagogy (20.06.1961-27.04.1966)

3. V.Lāča Liepaja State Institute of Pedagogy (28.04.1966-January, 1990)

4. Liepaja Institute of Pedagogy (February,1990-10.02.1993)

5. Liepaja Higher School of Pedagogy (11.02.1993-08.06.1998)

6. Liepaja Academy of Pedagogy (09.06.1998-15.07.2008)

7. Liepaja University (since 16.07.2008)

In 2014, Liepaja University was accredited as a state higher education institution offering study programmes on all three levels: Bachelor, Master, and Doctoral. It was the only university located in the Western part of Latvia, in the Kurzeme region, and can be considered a small, regional higher education institution.

Initially, this HEI offered teacher training for preschools, primary schools and teachers specialising in mathematics and Latvian language and literature. Since 1990 it has also added non-pedagogical study programmes, with the aim of shifting from a single-profile HEI to a multi-profile institution offering a broad spectrum of study programmes. Eventually in 2008 , it became Liepaja University and 
by 2014 had four faculties and offered 34 study programmes in social sciences, business, humanities and arts, natural sciences, mathematics, IT, pedagogic and educational sciences, and social welfare. The university employed 101 academic staff, of which 53 had a PhD degree.

Source: Developed by authors based on Saeima 2008.

The state steers the differentiation of the higher education system through accreditation and licencing. Licensed study paths encompass various study programmes offered by HEIs (Saeima 1995a). The primary purpose of this process is higher education quality assurance, confirming that HEIs have sufficient resources to carry out their intended study programmes rather than enforcing a specific profile (Cabinet Regulations 407 2015; Cabinet Regulations 408 2015). The higher education quality assurance system, which is primarily based on accrediting study paths rather than study programmes, was introduced in Latvia in 2011 in the context of reforms related to the Bologna Process (Saeima 1995a).

The HEI quality assurance reform was a result of ongoing effort to achieve better performance. Substantial institutional autonomy was regarded as another way to improve the quality of higher education, allowing institutions more flexibility in their institutional development decisions. From the start in 1995, there was an emphasis on HEI institutional autonomy, but substantial transformation only took place in 2006 when HEI law (Saeima 1995a) was amended to increase the autonomy of public HEIs.

Despite substantial financial autonomy, public HEIs in Latvia found themselves in very challenging circumstances between 2009 and 2014, because overcoming the economic crisis of 2009 required significant cuts in the public budget (Aslund and Dombrovskis 2011). The World Bank found the Latvian HEI funding system to be contingent on basic funding only, and thus it does not follow the European trend. Based on the recommendations of the World Bank, the government of Latvia initiated a reform of the national higher education funding model to eventually introduce a three pillar financing model (World Bank 2014b). The introduction of the new funding model was gradual and started in 2015. Public funding to HEIs became available on the basis of the first and the second pillar, that is, basic funding and ex post performance funding (Cabinet 
Regulations 994 2006). The third pillar is organised around innovationoriented funding.

While public HEIs in Latvia enjoy a high degree of financial autonomy in comparison with their European counterparts, public HEIs remain more regulated by the state than private HEIs. As recipients of public funding, public HEIs are, for instance, required to observe more restrictive rules on the language of instruction than private HEIs.

\section{Language of Instruction and Internationalisation}

In 1998, the Parliament of Latvia passed the Law on Education (Saeima 1998), which in combination with the Official Language Law (Saeima 1999) and the Law on Higher Education Establishments (Saeima 1995a) stipulated Latvian as the language of instruction in public HEIs. One of the key reasons for such a national language policy in public higher education was to ensure that Latvian as the official state language is used and developed in national higher education (Klava et al. 2010, 14). It was also argued that the aim of such a language policy is to avoid English becoming the single language used in higher education and research in the country, given its international dominance. A further but related aim is to maintain and develop terminology in the national language to be used in research in order to ensure the quality of higher education studies. Also, there was acknowledgement of the fact that the level of English language among academic staff and students might not be sufficient for effective use (Davidsen-Nielsen 2010; Druviete 1998). By 2014, several amendments to the law enabled public HEIs in Latvia to carry out study programmes in the official EU languages, including English, if certain preconditions are met.

Private HEIs on the other hand were more advantaged regarding the use of a foreign language of instruction in Latvia. They were able to offer HE study programmes not only in English but also in Russian, which is not an official EU language. Although there was a portion of international students at private HEIs in Latvia studying in Russian, evidence shows that these programmes mainly catered to the local Russianspeaking student population (Kaša and Ait Si Mhamed 2013). Restrictions on the use of foreign languages in higher education instruction for public HEIs have contributed to the diversification between public and private HEIs in Latvia; each caters to different pools of the student population. However, it should be mentioned that there are exceptions 
with English-taught public higher education in social sciences, law and business. These academic entities were established in the 1990s with special governmental support in order to modernise instruction in the aforementioned fields (Dovladbekova et al. 2006; Riga Business School 2015; RGSL 2014; Saeima 1995b). All of these cases involved collaboration with Western HEIs and presented another trajectory in post-Soviet higher education system diversification.

With the exception of the Stockholm School of Economics in Riga (SSE Riga), which from the very start was established to educate students from all three Baltic countries (Saeima 1995b), all other public institutions offering study programmes in a foreign language of instruction have evolved to enrol an increasing number of international students. In 1995, there were 648 international degree-seeking students studying at public and private HEIs in Latvia, compared to 5293 in 2014 (MoES 2014). Internationally mobile students in Latvia originated from a vast number of countries in the East and West (Kaša and Ait Si Mhamed 2013). By the end of the first decade of the new millennium, international students from former Soviet Union countries acquiring higher education in the Russian language mainly enrolled in the private HE sector (Priednieks and Kukliča 2012). The majority of degree-seeking international students studying in English mainly come from other EU countries and choose the HE public sector. The most popular study programmes in the English language among internationally mobile students were programmes in business, medical sciences and social sciences. The most popular programmes in Russian among international students included information technologies, logistics and business (Kaša and Ait Si Mhamed 2013).

Nearly all international students as well as the largest share of local students study at HEIs located in the capital of Riga (MoES 2014). Riga is home to the largest public and private HEIs in the country. However, the availability of higher education in other regions during the post-Soviet period increased with the opening of new public HEIs in the Western and Northern parts of the country. Some HEIs outside the capital that were narrowly specialised in Soviet times have also evolved into universities. In addition, many private and public HEIs have branches operating in major regional towns. From the perspective of institutional diversity, the regionalisation of higher education in post-Soviet Latvia has contributed to more choices for higher education seekers. However, Riga is still the central destination for students and its attractiveness contributes to migration from the regions. 


\section{Factors of Diversification}

Since national independence in 1990, there has been a steep increase in the demand for modern higher education training in the social sciences, which was not available during the Soviet era driven by Marxist-Leninist ideology. This contributed to the expansion of higher education in the social sciences (see Fig. 10.4). Another factor driving student demand in the social sciences was the secondary education reform in the early 1990s, which gave high school students the choice of focusing on the social sciences and humanities or mathematics and natural sciences. As the government did not incentivise private HEIs to develop study programmes in the hard sciences, this HE sector is limited to study programmes in social sciences, commerce and information technology. Study programmes in natural sciences and engineering are clustered in the public HE sector only.

Another aspect of higher education diversification by student characteristics is age. As explained earlier, higher education participation in postSoviet Latvia doubled and tripled at its peak in 2005 as compared to 1990 (Fig. 10.3). In the 2000s, the prevalence of traditional students aged 17-23 started diminishing and the proportion of non-traditional or mature-age students increased. This shift in the demographic composition of higher education students was driven by demographic changes in terms of smaller youth cohorts, as well as the necessity of engaging in life-long

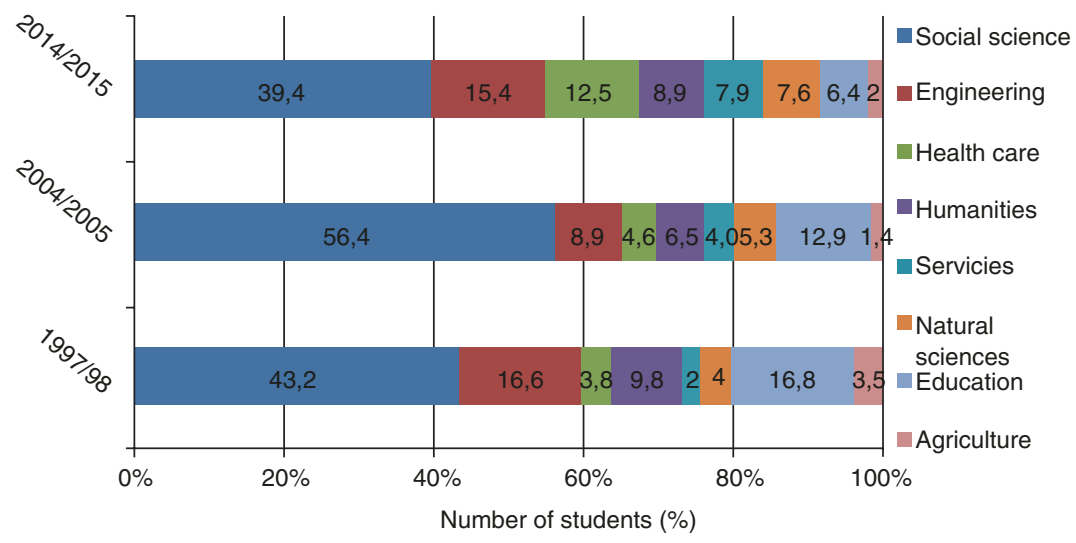

Fig. 10.4 Proportion of the number of students in different fields of study (Source: Authors based on data from MoES 1998 to 2014) 


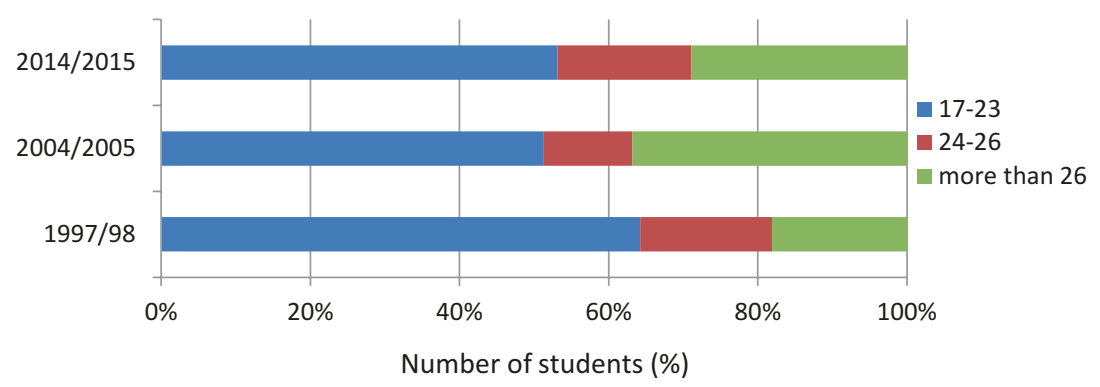

Fig. 10.5 Proportion of students by age group (Source: Authors based on data from MoES 1998 to 2014)

learning to upgrade education obtained during Soviet times. In 2014, nearly 30\% of all students in Latvia were older than 26 (Fig. 10.5).

At the HEI level, however, there have not been significant differences in student clustering by age. In 2014, all HEIs showed a relatively similar distribution of students by age (MoES 2015). Thus, while there was a system-level trend towards a more diverse age composition of $\mathrm{HE}$ students, there was no significant diversification by this factor among HEIs in Latvia.

The overall observation about HE system diversification from 1990 to 2014 , with a focus on programme provision and student characteristics, suggests that institutional autonomy has enabled most HEIs in the country to engage with demands and expectations in rather similar ways. An exception here is language policy in higher education, which has limited public HEIs in delivering study programmes in non-official EU languages such as Russian. This has instead been an area of activity for private HEIs in Latvia. On the other hand, private HEIs did not have the capacity to offer study programmes in natural sciences, as such institutional development was not incentivised by the government. Although there were formal governmental regulations allowing private HEIs to request public funding for programmes that are unique and competitive in the national HE market (World Bank 2014a), the government continued to provide direct funding to public HEIs only. Cases in which private HEIs receive public funding to implement study programmes are therefore the exception rather than the rule. Because public funding was also limited in the public HEI sector, all HEIs were sensitive to the market demand for higher education. 


\section{Typology of Higher Education Institutions in Latvia}

By 2014, several types of HEIs in Latvia had emerged in terms of the range of study programmes offered. One type includes specialised HEIs offering study programmes in only one area, like the National Defence Academy or the College of Medicine. The second type of HEI offers study programmes in two to four areas, and the third type is multidisciplinary, offering study programmes in five or more areas. Changes in study programmes offered in various areas by HEIs reflect institutional ability to develop new study programmes in new areas in an attempt to develop competitiveness in higher education markets.

The type of specialisation, however, was not the only characteristic which distinguished different types of institutions, especially since they reacted to market pressures in similar ways. There were additional characteristics such as primary function: teaching or research, location, ownership, size, levels of study. When taking into account this set of characteristics, HEIs in Latvia can be placed into seven groups consisting of flagships, regional HEIs, public specialised HEIs, internationally developed specialised HEIs with English as the language of instruction, private HEIs, both public and private colleges, and branches of foreign HEIs (see also Table 10.2).

In 2014, the University of Latvia and the Riga Technical University qualified as flagships of the HE system. They enrolled one-third of all students in Latvia (MoES 2015). Both of these HEIs have a history that precedes the Soviet era. In the years after independence since 1990, the University of Latvia has developed into the most comprehensive HEI in the country. While the focus of the Riga Technical University (RTU) has remained largely on technical sciences, it has also expanded since 1990 by developing study programmes in social sciences and business. Both the University of Latvia and RTU are multidisciplinary HEIs which offer undergraduate, graduate and advanced graduate/ $\mathrm{PhD}$ study programmes. They are important research centres of national and international orientation.

The second type of HEI, regional HEIs, encompasses public institutions established both prior to and after the independence of Latvia in 1990. These HEIs are located outside the capital of Riga in the regional centres of the country. The University of Applied Sciences and Ventspils University College are both newly established regional HEIs with the primary objective of developing regionally accessible higher education. The remaining 
Table 10.2 Types of HEI in Latvia by 2015 characteristics and ministerial affiliation

\begin{tabular}{|c|c|c|}
\hline Type of HEI & Number of HEIs & Ministerial oversight \\
\hline Flagships & 2 HEIs & \\
\hline \multirow{5}{*}{$\begin{array}{l}\text { Public, located in Riga, } \\
\text { multidisciplinary, important } \\
\text { research centres, undergraduate } \\
\text { through advanced graduate } \\
\text { study programmes, national and } \\
\text { international orientation }\end{array}$} & \multirow[t]{3}{*}{ University of Latvia } & The Ministry of \\
\hline & & Education and \\
\hline & & Science (MoES) \\
\hline & Riga Technical University & MoES \\
\hline & & \\
\hline Regional HEIs & 5 HEIs & \\
\hline \multirow{7}{*}{$\begin{array}{l}\text { Public, located in regional } \\
\text { centres, multidisciplinary, } \\
\text { teaching and research, } \\
\text { undergraduate and advanced } \\
\text { graduate study programmes, } \\
\text { significant regional orientation }\end{array}$} & Vidzeme University of Applied & MoES \\
\hline & Sciences & \\
\hline & Ventspils University College & MoES \\
\hline & University of Liepaja, & \multirow{4}{*}{ MoES } \\
\hline & Daugavpils University, & \\
\hline & Rezekne Higher Education & \\
\hline & Institution & \\
\hline Public specialised HEIs & $10 \mathrm{HEIs}$ & \\
\hline \multirow{14}{*}{$\begin{array}{l}\text { Public, specialised or narrow } \\
\text { specialisation, teaching, research, } \\
\text { undergraduate, graduate, and in } \\
\text { some cases advanced graduate } \\
\text { study programmes, national and } \\
\text { international orientation }\end{array}$} & Latvia University of Agriculture & $\begin{array}{l}\text { The Ministry of } \\
\text { Agriculture }\end{array}$ \\
\hline & Riga Stradins University & The Ministry of \\
\hline & Jāzeps Vitols Latvian Academy & The Ministry of \\
\hline & of Music, & Culture \\
\hline & Art Academy of Latvia & \\
\hline & Latvian Academy of Culture & $\begin{array}{l}\text { The Ministry of } \\
\text { Culture }\end{array}$ \\
\hline & Latvian Maritime Academy & MoES \\
\hline & Latvian Academy of Sports & MoES \\
\hline & Education & \\
\hline & Riga Teacher Training and & MoES \\
\hline & Educational Management & \\
\hline & Academy (RPIVA) & \\
\hline & $\begin{array}{l}\text { BA School of Business and } \\
\text { Finance }\end{array}$ & MoES \\
\hline & National Defence Academy & $\begin{array}{l}\text { The Ministry of } \\
\text { Defence }\end{array}$ \\
\hline
\end{tabular}


Table 10.2 (continued)

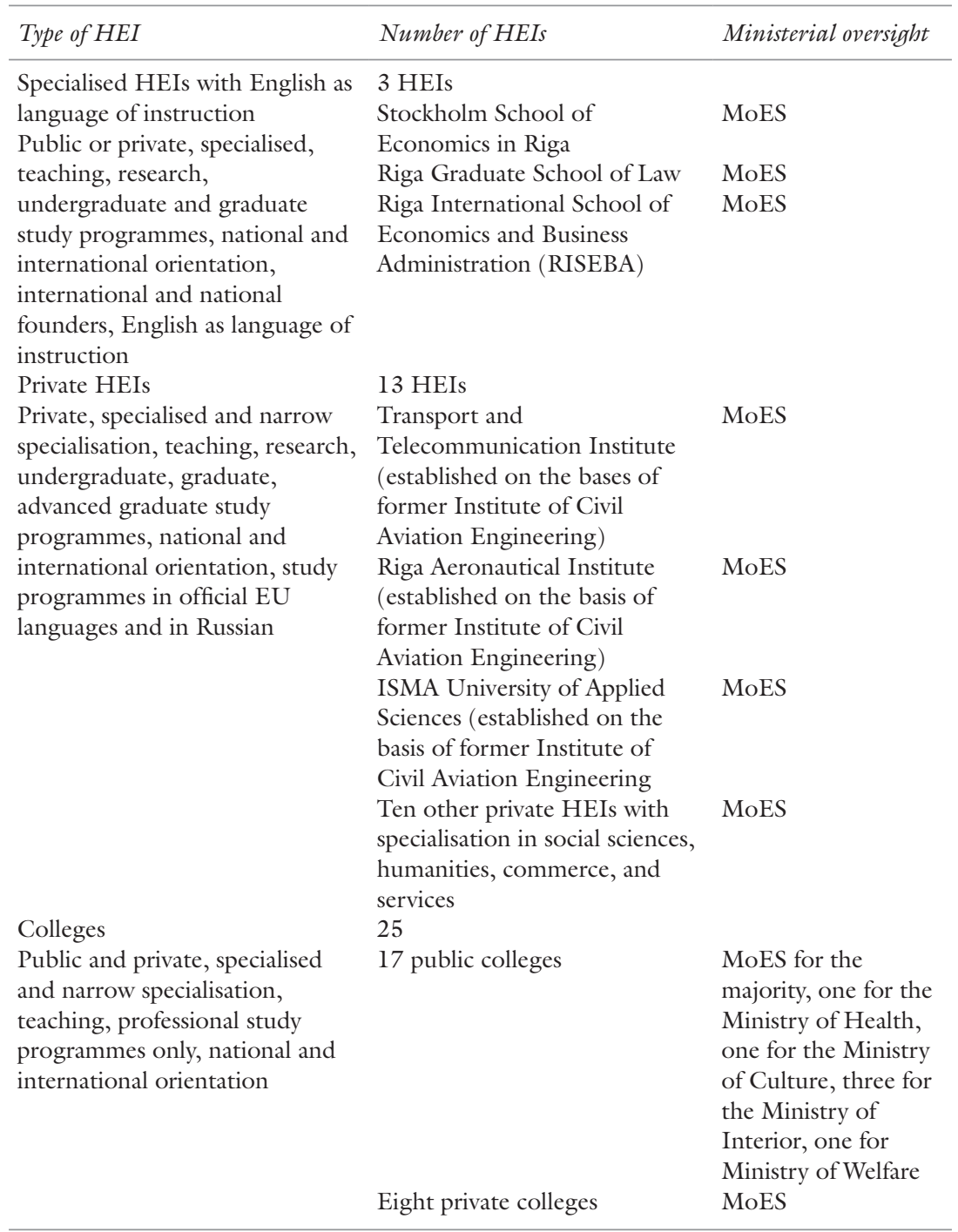


Table 10.2 (continued)

\begin{tabular}{lll}
\hline Type of HEI & Number of HEIs & Ministerial oversight \\
\hline Branches of foreign HEIs & 3 HEIs & \\
& Riga Higher Institute of & MoES \\
& Religious Sciences affiliated to & \\
the Pontifical Lateran & & \\
& University (RARZI) & \\
& Lateran Pontifical University \\
& Branch-Riga Institute of \\
& Theology \\
& Moscow State University of \\
& Economics, Statistics and \\
& Informatics (MESI) Riga \\
& branch \\
\hline
\end{tabular}

Source: Authors based on MoES data 2015, bylaws and HEI websites

three HEIs have evolved from an initially specialised focus on teacher education during Soviet times into multidisciplinary institutions. In 2014, all five HEIs were multidisciplinary in orientation and delivered undergraduate, graduate and PhD study programmes. While these HEIs are engaged in international projects and have a national orientation, they also have a strong regional focus in terms of responding to regional policies and human capital and cultural needs. The mission of these institutions includes both teaching and research.

The group of public specialised HEIs is comprised of ten institutions, six of which share past Soviet experiences and four of which were established after 1990. The newly established specialised HEIs each serve a specific purpose: national security, the development of the financial sector, the modernisation of pedagogical and management education, and the development of international intercultural relations. Among the other six HEIs, the most significant transformation took place with Riga Stradins University (RSU), known as the Riga Medical Institute during Soviet times. While this HEI has continued to provide education and research in medicine, it has also developed study programmes in social sciences. Other HEIs in this group have also somewhat diversified their offer of study programmes, but within their primary subject areas. All of these HEIs are focused on teaching, with various degrees of international and research engagement. 
Specialised HEIs with English as the language of instruction form a group of three institutions which were established as the result of major international collaboration. The Stockholm School of Economics in Riga was established in 1994, endorsed by the Latvian and Swedish governments with the purpose of providing state-of-the-art education in business and economics for the Baltic region (SSE Riga 2015). Providing state-of-the-art education in law and related social science fields, the Riga Graduate School of Law was established 1998 and is also supported by the governments of Latvia and Sweden (RGSL 2014). All of these HEIs teach exclusively in the English language, providing undergraduate and graduate education to students from Latvia and abroad. They have a strong international orientation and are also engaged in research.

The set of private HEIs in Latvia represents a diverse group of specialised and narrow specialisation institutions. This group is diverse in terms of historical heritage and contemporary focus. Three HEIs in this group have emerged from the former Soviet Institute of Civil Aviation Engineering. These HEIs maintain a focus on aviation and transportation systems. Other private HEIs have emerged in response to the post-1990 demand for higher education in social sciences, services, commerce and humanities. Most private HEIs in Latvia offer undergraduate and graduate study programmes, while others also offer PhD study programmes. Some are predominantly teaching oriented, although many are engaged in research activities with a national and international scope. An orientation to attract both national and international students is another characteristic of private HEIs in Latvia, which offer study programmes in English and Russian.

Colleges represent the sixth type of HEI. Both private and public colleges are the result of post-1990 legislative amendments in Latvia. While most public colleges share a Soviet past as vocational educational institutions, private colleges are the outcome of attempts to satisfy market demand in higher education after Latvian independence. All the colleges offer specialised first-level professional higher education. Although colleges predominantly enrol local students, some have a strong international orientation and all are engaged in international collaboration networks.

The last type of HEI, branches of foreign HEIs, is quite distinguished. In 2014, there were three such HEIs in Latvia. Of these, two were theological HEIs and one was a branch of the Moscow State University of Economics, Statistics and Informatics. The presence of such an HEI form did not exist in Soviet Latvia. Ministries overseeing HEIs remain the same 
as during Soviet times, creating unequal conditions for public HEIs depending on the wealth of each sector (World Bank 2014a). However, all HEIs in Latvia face similar higher education market conditions in terms of attracting tuition-paying students to their institutions.

\section{Conclusion}

Institutional history and the ability to respond to higher education market conditions have influenced how various HEIs have developed in Latvia. Compared to the Soviet period, the HE landscape has diversified. The Soviet HEI model with exclusively public and predominantly specialised HEIs has been replaced by a model of public and private specialised and multidisciplinary HEIs. The main drivers for this development were the liberalisation of the higher education sector and intensified demand for higher education among both traditional and non-traditional student age cohorts, especially in the social sciences (Kaša et al. 2016).

By 2014, the higher education landscape in Latvia consisted of 35 university and non-university HEIs offering both academic and professional study programmes, as well as 25 colleges offering short-cycle or professional first-degree higher education programmes. Furthermore, after 1990 HEIs in Latvia were longer operating in a secluded higher education space. On the contrary, integration into the EHEA and the internationalisation of higher education became an important national goal in the scope of higher education reform. EU membership provided conditions for the free movement of persons in Europe and supported student ability to travel abroad. Hence, Latvian HEIs no longer compete only on the national level (Cunska 2012). They face global competition for both local and international students, a condition unknown prior to 1990.

Given the context of a demographically shrinking student age cohort as well as national engagement with European higher education policy initiatives, migration and fluctuating economic conditions, it is likely that transformations of the institutional landscape in Latvia have only just begun.

\section{REFERENCES}

Aslund, A., and V. Dombrovskis. 2011. How Latvia Came Though the Financial Crisis. Washington, DC: Peterson Institute for International Economics.

Cabinet Regulations 407. 2015. Augstskolu, koledžu un studiju virzienu akreditācijas noteikumi [Regulations on the Accreditation of Higher Educational 
Institutions, Colleges, and Study Directions]. Latvijas Vestnesis 146(5464). http://likumi.lv/ta/id/275560-augstskolu-koledzu-un-studiju-virzienuakreditacijas-noteikumi. Accessed l Oct 2015.

Cabinet Regulations 408. 2015. Studiju programmu licencēšanas noteikumi [Regulations on the Licensing of the Study Programmes]. Latvijas Vestnesis 146(5464). http://likumi.lv/ta/id/275563-studiju-programmu-licencesanasnoteikumi. Accessed 1 Oct 2015.

Cabinet Regulations 846. 2006. Noteikumi par prasībām, kritērijiem un kārtību uzņemšanai studiju programmās [Regulations on the Requirements, Criteria and Procedure for Admission to Study Programmes]. Latpijas Vestnesis 172(3540). http://likumi.lv/ta/id/275563-studiju-programmu-licencesanas-noteikumi. Accessed 1 Oct 2015.

Cabinet Regulations 994. 2006. Kārtība, kādā augstskolas un koledžas tiek finansētas no valsts budžeta lidzekliem [Regulations on the Procedure of State Budget Financing to Institutions of Higher Education and Colleges]. Latvijas Vestnesis 200(3568). http://likumi.lv/doc.php?id=149900. Accessed 27 Sept 2015 .

Cunska, Z. 2012. Iedz̄ivotāju izglitīibas limmenis Latvijā. [Level of Education of Inhabitants of Latvia]. In Universitā̌su ieguldījums Latvijas tautsaimniecībō [The Contribution of Universities to the Economy of Latvia], 17-29. Riga: Latvijas Universitāšu asociācija.

Davidsen-Nielsen, N. 2010. Language in Higher Education: A Danish View. In National Languages in Higher Education, ed. M. Humar and M.Ž. Karer, 87-90. Ljubljana: ZRC Publishing.

DeWitt, N. 1955. Soviet Professional Manpower: Its Education, Training and Supply. Washington, DC: National Science Foundation.

Dobson, R. 1977. Social Status and Inequality of Access to Higher Education. In Power and Ideology in Education, ed. J. Karabel and A.H. Halsey, 245-274. New York: Oxford University Press.

Dovladbekova, I., T. Muravska, and T. Paas. 2006. Transformation of Higher Education as the Precondition for Competitive Development in Estonia and Latvia. European Legacy 11 (2): 171-184. doi:10.1080/10848770600587953.

Druviete, I. 1998. Latvijas valodas politika Eiropas Savienības kontekstā. Rīga: Latvijas Zinātņu Akadēmijas Ekonomikas insitutūts.

Eglìte, P. 2009. Padomju okupācijas demogrāiskās, sociālās un morāāās sekas Latvijā. Latvijas Zinātņu Akadēmijas Vestis 63(1/2): 86-106. http://www. lza.lv/LZA_VestisA/65_3-4/6_Eglite_Padomju okupac.pdf. Accessed l Oct 2015.

EUA. 2012. EUA's Public Funding Observatory. Brussels: European University Association. 
Eurydice. 2014. The Structure of the European Higher Education Systems 2014/15: Schematic Diagrams. http://eacea.ec.europa.eu/education/eurydice/facts_ and_figures_en.php\#diagrams. Accessed 1 Oct 2015.

Heyneman, S.P. 2000. Educational Evaluation and Policy Analysis. Educational Evaluation and Policy Analysis 22(2): 173-191. http://www.jstor.org/stable/1164394. Accessed 4 Dec 2015.

Karklins, R. 1984. Ethnic Politics and Access to Higher Education: The Soviet Case. Comparative Politics 16 (3): 277-294.

Kaša, R. 2007. Devolution of Student Financial Assistance in Latvia. Unpublished PhD dissertation, SUNY Buffalo, Buffalo.

Kaša, R., and A. Ait Si Mhamed. 2013. Language Policy and Internationalization of Higher Education in the Baltic Countries. European Education 45 (2): 28-50.

Kaša, R., and Z. Loža. 2001. The State Financing for Higher Education: Financial Flow Mechanisms. In A Passport to Social Cobesion and Economic Prosperity: Report on Education in Latvia 2000, ed. G. Catlaks, I. Dedze, S. Heyneman, and K. Krēsliņš, 14-26. Riga: Soros Foundation - Latvia.

Kaša, R., A. Ait Si Mhamed, I. Dedze, and Z. Cunska. 2016. Trajectories of Higher Education Massification in Latvia. HERB 2 (8): 27-28.

Klava, G., K. Klave, and K. Motivāne. 2010. Latviešu valodas prasme un lietojums augstākās izglītības iestādēs: mazākumtautību izglītības satura reformas rezultāti [Knowledge and Use of Latvian Language at the Institutions of Higher Education: The Results of the Curriculum Reform at Ethnic Minority Schools]. Rīga: Latviešu valodas agentūra.

LE. 2002. Latvijas Enciklopēdija [Encyclopaedia of Latvia], Volume 1, Entry "Augstākā izglītība" pp: 378-379. SIA "Valērija Belokoņa izdevniecība", Rìga.

LPE1. 1981. In Latvijas padomju enciklopèdija. 1. Séjums [Encyclopaedia of Soviet Latvia. Volume 1], ed. P. Jērāns and S. Ziemelis. Rīga: Galvenā enciklopēdiju redakcija.

LPE5. 1984. In Latvijas padomju enciklopèdija. 5. Sejums [Encyclopaedia of Soviet Latvia. Volume 5], ed. P. Jērāns and S. Ziemelis. Rīga: Galvenā enciklopēdiju redakcija.

LU. 1999. In Latvijas Valsts universitātes vēsture, 1940-1990 [History of the State University of Latvia, 1940-1990], ed. H. Strods. Rìga: Latvijas Universitāte.

- 2014. Latvijas Universitāte. Vēsture. [History of the University of Latvia]. http://www.lu.lv/par/vts/vesture/. Accessed 12 Jan 2014.

LVU. 1982. P. Stučkas Latvijas Valsts Universitāte. [Latvia State University of P. Stučka]. Riga: Avots. 
MoES. 1998. Pārskats par Latvijas angstskolu darbību 1998. gadā. [Annual Report on Latvia's Higher Education in 1998]. Riga: The Ministry of Education and Science.

- 2014. Pārskats par Latvijas augstāko izglītību 2013. gad̄̄ (galvenie statistikas dati) [Review on Higher Education in Latvia in 2013: Main Statistical Indicatotrs]. Riga: Ministry of Education and Science.

- 2015. Pārskats par Latvijas angstāko izglìtību 2014. gad̄̄ [A Review on Higher Education in Latvia in 2014]. Rīga: Izglitîbas un zinātnes ministrija.

Norgaard, O., L. Johannsen, M. Skak, and R.H. Sorensen. 1999. The Baltic States After Independance. 2nd ed. Northampton: Edward Elgar Publishing.

Pachuashvili, M. 2009. The Politics of Higher Education: Governmental Policy Choices and Private Higher Education in Post-Communist Countries. http:// web.ceu.hu/polsci/dissertations/Marie_Pachuashvili.pdf. Accessed 25 Oct 2011.

Priednieks, A., and I. Kukliča. 2012. Augstākās izglitīibas eksports. [Export of Higher Education]. In Universitāšsu ieguldījums Latvijas tautsaimniecībā [The Contribution of Universities to the Economy of Latvia], 56-65. Rīga: Latvijas Universitāšu asociācija.

RGSL. 2014. Riga Graduate School of Law (RGSL) History. http://www.rgsl. edu.lv/en/inside-rgsl/about/history/. Accessed 5 Dec 2015.

Riga Business School. 2015. RTU Riga Business School. http://www.rbs.lv/ about-rbs/about-rbs. Accessed 5 Dec 2015.

Rivža, B. 2004. The Structure of the Higher Education System and the Role of Research. In UNESCO Forum Occasional Paper Series Paper No. 6. Diversification of Higher Education and the Changing Role of Knowledge and Research (ED-2006/W ed.), 70-82. Paris: UNESCO.

RTU. 2002. Augstākās tehniskās izglìtības vēsture Latvijā, 1. dala [The History of Technical Higher Education in Latvia: Part One]. Rīga: Rīgas Tehniskā universitāte.

- 2013. Rūgas Tehniskā Universitāte. Vesture [History of Riga Technical University]. http://www.rtu.lv/content/view/19/924/lang,lv/. Accessed 3 Dec 2015.

Saeima. 1995a. Augstskolu likums [The Law on Higher Education Establishments]. Latvijas Vestnesis 179(462). http://likumi.lv/doc.php?id=37967. Accessed 27 Sept 2015.

. 1995b. Par Rīgas Ekonomikas augstskolu [About Stockholm School of Economics in Riga]. Latvijas Vestnesis 164/165. http://likumi.lv/doc. php?id=37448. Accessed 5 Dec 2015.

. 1998. Izglitīibas likums [The Law on Education]. Latvijas Vestnesis 343/344. http://likumi.lv/doc.php?id=50759. Accessed l Oct 2015. 
1999. Valsts valodas likums [Official Language Law]. Latvijas Vestnesis 428/433. http://likumi.lv/doc.php?id=14740. Accessed l Jan 2015.

- 2008. Likums "Par Liepājas Universitātes Satversmi" [Law 'On the Constitution of Liepaja University']. Latvijas Vestnesis 100(3884). http:// likumi.lv/doc.php?id=177519. Accessed 10 Oct 2015.

SSE Riga. 2015. SSE Riga Mission and History. http://www.sseriga.edu/en/ about/overview/mission-and-history/. Accessed 5 Dec 2015.

Štefenhagena, D. 2012. Universitātes regulējošais tiesiskais ietvars [The Legal Regulatory Framework of Universities]. In Universitāš̀n ieguldījums Latvijas tautsaimniecība [The Contribution of Universities to the Economy of Latvia], 39-49. Rīga: Latvijas Universitāšu Asociācija.

Walder, A. 1990. The Political Dimension of Social Mobility in Communist States: Reflections on the Soviet Union and China. In The Political Sociology of the State: Essays on the Origins, Structure, and Impact of the Modern State, ed. R. Braungart and M. Braungart, 49-66. London: JAI Press Inc.

World Bank. 2014a. Higher Education Financing in Latvia: Analysis of Strengths and Weaknesses. World Bank Reimbursable Advisory Service on Higher Education Financing in Latvia. http://www.izm.gov.lv/images/izglitiba_ augst/03.pdf. Accessed 22 Aug 2015.

- 2014b. Higher Education Financing in Latvia: Final Report. World Bank Reimbursable Advisory Service on Higher Education Financing in Latvia. http://www.izm.gov.lv/images/izglitiba_augst/06.pdf. Accessed 22 Aug 2015.

Ali Ait Si Mhamed is currently an Associate Professor at Nazarbayev University Graduate School of Education, Astana, Kazakhstan, where he also serves as a member of the Policy Research Project "Development of Strategic Directions for Education Reforms in Kazakhstan", 2015-2020. He has a PhD in Comparative Education from the State University of New York in Buffalo, USA, and extensive teaching experience internationally (USA, Morocco, Latvia and Kazakhstan). Moreover, he was a World Bank Consultant on issues of finance of higher education. He has examined financial aid systems in Moroccan and Latvian higher education. Dr. Ali Ait Si Mhamed was a Fulbright Scholar from the USA to Latvia in 2011-2012.

Zane Vārpiņa obtained a PhD in Demography with specialisation in socioeconomic demography (Dr.demogr.) from the University of Latvia and has an MA of Science in Mathematical Economics from the same university. She also has an Inter-university Diploma in EU Studies, Université Nancy II, Aix-en-Provence Institute of Political Science. Zane Vārpiņa is Assistant professor at Stockholm School of Economics, Riga, since 2013. Zane Vārpiņa has research experience in 
the Baltic International Centre for Economic Policy Studies (BICEPS). Her main research interests include higher education and demography.

Indra Dedze holds a PhD degree in International Comparative Education from Stockholm University. Currently she is working at the University of Latvia. From 2009 to 2013, she was national research coordinator for Latvia for the EUROSTUDENT IV project. For several years she worked at NGOs: the Soros Foundation-Latvia, Centre for Public Policy PROVIDUS in Latvia and the Open Society Institute in Budapest. In all these organisations, Dedze was responsible for research projects in the field of Education Policy including cooperation with the NGO networks in Central Asia and Eastern Europe and international organisations. As a Fulbright fellow, Dedze carried out research on the evaluation of higher education management at Vanderbilt University, USA (2004-05).

Rita Kaša holds a $\mathrm{PhD}$ in Comparative Education from the State University of New York in Buffalo (SUNY Buffalo), USA, and MA and BA in Political Science from the University of Latvia. Her research interests concern educational policy, finance and governance. She especially focuses on student financial assistance policies, equity and equality in educational access in the context of intensifying transnationalism and migration. Prior to her current position as an Assistant Professor at Nazarbayev University Graduate School of Education in Kazakhstan, Rita held academic and administrative positions at the Stockholm School of Economics in Riga, Latvia.

Open Access This chapter is distributed under the terms of the Creative Commons Attribution 4.0 International License (http://creativecommons.org/licenses/ by $/ 4.0 /)$, which permits use, duplication, adaptation, distribution and reproduction in any medium or format, as long as you give appropriate credit to the original author(s) and the source, provide a link to the Creative Commons license and indicate if changes were made.

The images or other third party material in this chapter are included in the chapter's Creative Commons license, unless indicated otherwise in a credit line to the material. If material is not included in the chapter's Creative Commons license and your intended use is not permitted by statutory regulation or exceeds the permitted use, you will need to obtain permission directly from the copyright holder.

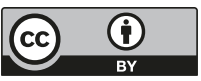

